\title{
Stability or Stagnation, or Why the School is not the Way Reformers Would Like ${ }^{1}$
}

\author{
Estabilidad o Estancamiento, \\ o Por Qué la Escuela no es lo Que los \\ Reformistas Quisieran que Fuera
}

\section{La Stabilité ou la Stagnation, ou Pourquoi l'École n'est pas la Voie que Réformateurs Aimerions}

\author{
Daniel Tröhler \\ University of Luxembourg
}

\section{ABSTRACT}

The school has always been understood as a kind of technological medium for realization of visions of social justice and progress. And as different as these visions of the future are, the protagonists were and are always in very strong agreement that the school is not fulfilling the role intended for it. Reforms that falter, however, do not usually lead to reflection and contemplation but instead to new strategies, in the hope that different means can achieve the success that earlier efforts failed to produce. Reforms follow reforms, new models replace models only just initiated, and the unrest in the field can at times assume alarming proportions, serving more to hinder than strengthen the professional efforts of the actors involved. This paper examines the most recent phase of educational reform heading for efficiency by testing two prominent theories about the persistence of the school system, the so-called Neo-Institutionalism and the Grammar-of-Schooling thesis.

Key words: school reform, A Nation at Risk, output steering, Neo-Institutionalism, Grammar of Schooling.

\section{RESUMEN}

La Escuela ha sido entendida como una especie de medio tecnológico para la realización de visiones de justicia social y progreso. Más allá de las diferencias que han existido entre las visiones 
del futuro, hay acuerdo que la escuela no ha desempeñado su papel como se esperaba que lo hiciera. Sin embargo, las reformas no conducen a un proceso de reflexión y contemplación, sino que proveen nuevas estrategias con la esperanza de que medios diferentes puedan llevar al éxito que esfuerzos anteriores no lograron alcanzar. Una reforma sigue a la otra, nuevos modelos reemplazan modelos iniciados poco tiempo antes y la insatisfacción asume, a veces, proporciones alarmantes al punto que llega a obstaculizar en vez de apoyar los esfuerzos profesionales de los actores. Este artículo examina la fase más reciente de reforma educacional motivada por la búsqueda de eficiencia a través de la evaluación de dos teorías prominentes sobre la persistencia del sistema escolar, ellas son la teor a neo-institucionalista y la tesis conocida como la gramática de la educación escolarizada.

Descriptores: reforma educacional, A Nation at Risk, rendimiento, neo-institucionalismo, gramática de la educación escolarizada.

\section{RÉSUMÉ}

L'école a toujours été perçue comme une sorte de médium technologique pour réaliser des visions de justice sociale et de progrès. Et aussi variées que soient ces visions d'avenir, les protagonistes furent toujours et sont encore d'accord que l'école ne remplit pas le rôle voulu pour elle. Toutefois, les réformes défaillantes ne conduisent pas ordinairement à la réflexion et à la contemplation mais plutôt à de nouvelles stratégies, dans l'espoir que des moyens différents puissent atteindre le succès que les efforts précédents n'ont pas réussi à produire. Les réformes se succèdent, de nouveaux modèles remplacent ceux qui viennent juste d'être initiés, et les troubles dans le domaine peuvent parfois prendre d'inquiétantes proportions, qui servent davantage à brimer qu'à renforcer les efforts professionnels des acteurs impliqués. Ce papier examine la phase la plus récente de la réforme éducative dont le but est l'efficacité en mettant à l'essai deux théories célèbres au sujet de la persistance du système scolaire : le soi-disant néoinstitutionnalisme et la thèse de la "grammaire de l'école. "

Mot-clés: La réforme scolaire, une nation à risque, une direction de rendement, le néoinstitutionnalisme, la grammaire de l'école.

W

ITHIN THE FIELD OF EDUCATION it is taken for granted that the eighteenth century was a century of education. This description usually serves to indicate that in the eighteenth century, education was able to develop its modern issues and insights, and in this connection it almost automatically refers to a specific event, namely, the publication in 1762 of Jean-Jacques Rousseau's novel about education, Emile. ${ }^{2}$ According to the common topos, it is in that novel that childhood is discovered to be a life phase of its own, a phase to be protected and not sacrificed to an uncertain future. The conclusion drawn is that modern education is child-friendly education, and because the child is a natural thing, modern education is also natural education.

But there are good reasons not to view this concept as modern. Not only because it is doubtful that - like in Rousseau's Emile - each child could be assigned his or her own tutor, who would work lifelong without pay and at the end of the pupil's education would not only choose the pupil's spouse but also be assigned to tutor the new couple's children. Even the fact that in Rousseau's novel there is no school and learning by instruction is long delayed, is not sufficient to mark the book as old-fashioned. Much more crucial is a very specific idea that was developed in the eighteenth century and not by Rousseau, an idea that does not make education modern but instead raises education to a project of the modern age. This was the first development of the idea that education can solve societal problems prospectively, that 
education was therefore always connected with questions of society's progress towards greater justice and prosperity. This socially progressive idea is definitely not found in Emile. The boy Emile is raised outside society, and his wife is chosen for him; in the end he is not even capable of bringing up his own children. What is more, he ends in total disaster, as reported in Rousseau's hardly ever read, unfinished novel Émile et Sophie ou les Solitaires. ${ }^{3}$ In this work, namely, his wife Sophie is unfaithful to him, and becomes pregnant by another man. In response, Emile flees France, gets kidnapped during his escape, and finally ends up in Algeria as a head slave.

In contrast to that scenario, the education of the eighteenth century as a project of the modern age is much more optimistic and makes extensive promises. For this, the nineteenth century developed a specific organizational form, namely, the modern public school; it became the 'technology' of this progress and justice-oriented thinking. Whatever social, economic, or political problems arose, they were referred to the school, whose task it was to solve the problem prospectively. This thought pattern is still extremely attractive today - on a global level, too, if we think of the numerous projects that, for example, the World Bank undertakes in what is called the Third World. The development of the school system is always legitimized through the promise of greater economic prosperity and social justice. ${ }^{4}$

Unmistakably, however, the position of honor that education, or the school, could take as a project of the modern age also had drawbacks. For one, the developing school was never really able to live up to the noble ideas of societal salvation, and so it came to be criticized by those who were disappointed. For another, people were never able to agree upon what would constitute a better future. Depending on the historical period, the school was supposed to produce greater humanity, or more social equality, or then higher national superiority, greater community, or greater industrial efficiency, healthier athletes or soldiers, or better Christians. The discrepancy between high expectations and actual school results led to disillusionment, and blame was usually placed on the school system, curriculum, teachers, or teaching materials.

In the twentieth century we can distinguish - here leaving out National Socialism and the initial post-war period — at least three great visions that were associated with the school, or were supposed to be for the school as a 'technology,' an implementation tool. In the first decades of the twentieth century, and following Rousseau — that is, following a very specific reading of Rousseau - critical commentary was directed at the city, the industrial modern age, and, accordingly, schooling of the intellect alone, and the demand was made for natural, child-friendly, and integral education. In the 1960 s, society was viewed as unjustly structured, and a call was raised for social equity and equal opportunity, which the schools were to realize. The main catchword in the first reform phase was "nature"; in the second it was "equity," or "equality," or "justice." This second phase was then also superseded, this time by a vision that ties expectations for the future and not to nature or equity but to performance. The new catchword is "excellence," and connected with this term we find further terms such as assessment, controlling, monitoring, evaluation, or accountability. Accordingly, today organizations present themselves not using slogans such as "integrative approach" or "non-violence" but instead in terms of "leadership" or "excellence." 
These visions of the future represent the school as a kind of technological medium for realization of social justice and progress. And as different as these three phases of visions of the future are, the protagonists were and are always in very strong agreement that the school is not fulfilling the role intended for it. Reforms that falter, however, do not usually lead to reflection and contemplation but instead to new strategies, in the hope that different means can achieve the success that earlier efforts failed to produce. Reforms follow reforms, new models replace models only just initiated, and the unrest in the field can at times assume alarming proportions, serving more to hinder than strengthen the professional efforts of the actors involved.

In the following, I would like to examine the most recent of the phases sketched out above. It is my four-part thesis that:

- school education, is still today being understood, or misunderstood, as a kind of technology, or tool, for realizing visions of progress, justice, and the future;

- these ideas of the future are shaped decisively by economic considerations that find expression in the area of school education as measurable and comparable output, the ideal of which is called excellence;

- these visions, however, are hardly realizable in the sense hoped for, because school education is not a technology in the sense of a mechanical tool that can be used at will;

- and that instead, school education has its own, historically-evolved order or lawfulness that responds with reserve when faced with reform attempts. Reformers call this persistence or stagnation, whereas others praise it as stability.

I would like to establish proof of this extended hypothesis in five steps. First, I present the genesis of the new reform efforts (1.), and then show what problems these reforms have in practice and who is blamed for this (2.). In the third and fourth steps, I present two popular theoretical models that deal with the stability of school education (3./4.). In conclusion I show that in spite of all reform proposals and research on instruction, there is no way around either public expectations or what is compatible with the historically-evolved forms of schooling (5.).

\section{The New Wave of Reform since the 1980s: A Nation at Risk and the Consequences}

The distinctive economic vocabulary became established in the field of education in the United States after 1980, when with Ronald Reagan, a very conservative politician became President of the United States with the promise to restore to America the self-confidence and pride it had once enjoyed. President Reagan appointed Terrel $\mathrm{H}$. Bell (1921-1996) as Secretary of Education in January of 1981 (Reagan had pledged to abolish the Department of Education, and Bell was initially appointed with the expectation that he would preside over the dismantling of his department). Bell had served as a Marine in World War II and had a doctorate in education. Once appointed by Reagan, Bell set up the National Commission on Excellence in Education on August 21, 1981 and commissioned a report on the quality of education in the 
United States. The report was submitted on schedule on April 26, 1983 by the Commission members. The title of the report, A Nation at Risk: The Imperative for Educational Reform, ${ }^{5}$ already reveals much of the subject of the report. The response that it triggered was explosive. ${ }^{6}$

The report contributed a great deal in the changeover of the core term of educational policy from equity into excellence. ${ }^{7}$ The structure of the report is very revealing, because it does not begin with the subject of school achievements but instead with discussion of the economic position of the United States in international competition, which is assessed as very poor, implying the Nation at Risk. Although the report concedes that education is only one of the causes of this decline, "it is the one that undergirds American prosperity, security, and civility." ${ }^{8}$ The report goes on to say that the erosion of the education system was our own fault, that the nation had in effect "been committing an act of unthinking, unilateral educational disarmament", disarmament being a taboo word in the Reagan era.

Instead of explaining the relationship between education system and international economic competition - which is, by the way, a pattern of thought that today lies behind the PISA assessments - the report presents a historical pseudo-argument. This type of argument can be found whenever reform has been sought in the field of education; the lines of the argument are that "especially today," of all days, it is decisively important to change our thinking on education. The report hastens to assure the reader that the authors' concerns go beyond the national global economic perspective when seeking improvements in education. They are concerned also for the "intellectual, moral, and spiritual strengths of our people which knit together the very fabric of our society." 10

This special quality of American culture that apparently makes necessary a specific education is not explained subsequently in the text. Instead, another historical pseudo-argument is presented next; namely, the report takes recourse to an undisputed hero of the United States, Thomas Jefferson, the third president of the United States and author of the Declaration of Independence of 1776. Despite the fact that on the previous page of the report, it was emphasized that present times were so different and that new means were required to master them, the report now affirmatively quotes Jefferson from the year 1820, in which Jefferson pleads for comprehensive public education. ${ }^{11}$

Obviously, the argumentation in A Nation at Risk is rhetorical rather than intellectual, and it is against this background that it could suggest a unity of education, economic power, and a secured future. It is also quite evident that the report was able to pave the way for the success of criticism that had for some time been quite virulent. The criticism is based on a number of convictions that have found astonishingly little empirical support, despite the fact that their exponents make a big deal about the "data." The assumptions are the following:

- National economic prosperity is dependent upon the educational level of the population (output)

- National educational output can be determined by means of international comparisons (assessment, evaluation) 
- National output can be increased by means of intra-national comparisons and definitions of standards or content and performance expectations, based on which good schools (high performance) are rewarded with greater federal funding (incentives)

- Not only the setting of standards, but also monitoring of the schools should be overseen by experts (governance, steering)

- The addressees of standards-based reforms are the individual schools (school level initiative, site-based management).

The report $A$ Nation at Risk triggered a surge of almost thirty similar reports and related books ${ }^{12}$ and led to a number of rather costly reform activities that in the end proved to be not all too successful. This in turn increased disappointment in the school system and reinforced the reform rhetoric. But whatever efforts were undertaken, as to the results the school proved to stagnate or-depending on the point of view - to be stable. All of a sudden, a part of research changed its focus. Interest no longer centered on the failing schools but instead on the failing reforms. Many of the researchers believed that the reasons for the unloved dullness of the school, or the insufficient reforms, are to be found in local school boards, in other words, in public democratic control of the schools. This provided already traditional complaints directed towards the local school boards with new inspiration. Chester E. Finn, Jr., Professor of Education at Vanderbilt University in Tennessee, comparing schools to companies in private industry, called school boards "living fossils of an earlier age." 13

\section{The School Boards or the Democratic Control of the School}

Worldwide, as far as I know, there are only two or three nations that have democratically elected local school boards all over the country, namely, the United States and Switzerland, and some of the Canadian provinces, as well. The central idea of this democratic form of school control is that education is neither a private nor a state good but a public good. Education does not primarily serve private persons or the state but instead a public that in democracies can control the state and the people in power. In order to exercise this control, people need to be educated. Precisely because in this tradition education is conceived as a public good, the organization of education has to be controlled publicly, not by state experts but by locally elected 'normal' citizens. Citizens make up the school boards at the various levels of government administration, the town, the district, and the state. Thomas Jefferson, to whom $A$ Nation at Risk refers, was in favor of this public oversight of the school by laymen, a fact that the authors of the report concealed.

For David T. Conley, Professor of Educational Policy and Leadership, it is a foregone conclusion that the local school boards have too much influence and have acted on state government reform programs only with reluctance. ${ }^{14}$ In his view, the influence of the school boards should be restricted in order to reach a new balance between state government and the individual school and to push through the reform programs by means of incentives, so that the schools would at last produce better 
testing results. Therefore, says Conley, greater focus should be placed on output (testing results) than on input, as previously — input being methods, teacher education, teaching materials, and curriculum development. Here the individual schools are supposed to have relative autonomy as to how they wish to achieve these goals. The state governments would then serve as monitoring agencies and in this way ensure that state guidelines are met. In this reform, says Conley, the local school boards and the superintendents, however, are the "losers." ${ }^{15}$ Conley's answer to the question "What is the role of a local board in an educational governance system influenced by marked-based conceptions?" is that local school boards will serve the state government by helping to increase the accountability of the individual schools, and if they fail to do so, they should be passed over by the state. ${ }^{16}$ The new ideal is a top-down/ bottom-up model between state government and individual school. The role of the public is no longer control but rather optimization of the mutual relationship, consisting in guidelines and feedback on the evaluated achievements. ${ }^{17}$

Short-term implementation of the revolution from local democracy to centralized expertocracy was, of course, not possible, particularly not in contexts having a long local democratic tradition. While educational policy makers tried to find new ways of bypassing school boards or at least lessening their influence-one can interpret ideas such as the voucher system and the concept of charter schools as attempts in that direction - research on the other hand started to ask why it is not so easy to break the persistence of the school or to improve the performance of the school. Coincidentally or not, in answer to these questions two different departments at Stanford University, initially relatively independently of each other, have over the last thirty years developed theoretical models that deal in the broadest sense with the phenomena discussed here - namely, with the peculiar "behavior" of the school, or organizations in general. At the School of Education at Stanford, a model called the grammar of schooling was developed; the other model, developed at the Department of Sociology, is called neo-institutionalism.

\section{The Thesis of the Grammar of Schooling}

The thesis of the grammar of schooling model is a result of extensive historical studies of the fate of numerous school reform efforts of the past 120 years in the United States, the vast majority of which can be said to have failed. The studies led to the insight that schools are not or do not seem to be practically resistant to reform for the reason that teachers are too lethargic or classes too large, as was believed for a long time. Instead, the insight was that the school, or schooling, has its own grammar, which responds highly selectively to reforms. One of the exponents of the grammar of schooling ${ }^{18}$ likens reforms to hurricanes at sea, with "storm-tossed waves on the ocean surface, turbulent water a fathom down, and calm on the ocean floor." ${ }^{19}$ Once the storm passes, there is no reminder of the past surface turbulence. For the school system, this connection means that deep below the surface it possesses a structure that continues largely uninterrupted, its own regular structures and rules, its own grammar, that can not be changed without loss of the school's specific character. The 
central characteristics of this grammar are:

- dividing knowledge into identifiable school subjects

- distributing instruction in school subjects across identical time periods

- allocating students to grades by age

- regulating the transitions between the individual school levels and, along with that,

- assessing and certifying achievements. ${ }^{20}$

This grammar of schooling does not mean that the school is unchangeable, but it does say that reform always has to move within the current grammar. The conclusion is that if reformers want to prompt change, they must adapt their reform proposals to this grammar of schooling. Further-reaching efforts such as eliminating school subjects or certification, for example, fail in the long term, no matter how great the efforts are to push on with the reform. ${ }^{21}$ The traditional way of looking at school history, the grammar of schooling model concludes, has to be turned around. It was assumed previously, namely, that the history of the school was to be understood as the result of changes that were set off by reforms. But the assumption that the school has its own grammar that responds selectively to reforms turns the tables, so to speak: the main question in a history of the schools should not be How Reforms Changed Schools but rather How Schools Changed Reforms. ${ }^{22}$

We are used to viewing the school not as something with regular structures and rules of its own but rather as a tool to be implemented for realizing our visions for the future - something that just needs to be organized correctly so that it executes what we expect it to do. However, the school is apparently not a technology in the sense of mechanical physics but is instead a complex entity with a character of its own. It is the historical result of numerous attempts (mainly in the nineteenth century) to provide public schooling to the people as effectively as possible. This holds especially for the United States, which in the nineteenth century had to deal with schooling not only its own young but additionally also millions of immigrant children. In dealing with these tasks it was precisely the local school boards that had a stabilizing effect locally in a relatively unbureaucratic way. The demand to abolish the school boards voiced by many of the dominant school reformers today can in fact be supported by the argument that these specific problems of mass immigration in the nineteenth century are a thing of the past and the school boards a kind of fossil.

However, the plans to eliminate these institutions are being challenged by several interest groups, and it seems that the reformers face severe problems in their attempt to abolish or circumvent democratic control in the school system. The resistance indicates that new policies cannot be implemented without general cultural acceptance. Decisions to lessen democratic control of the school do not at the same time also eliminate the culturally anchored belief in the necessity of this kind of control of the school. The cultural convictions are much more persistent than the real-world organization of those convictions. These are collectively generated ideas, taken-for-granted assumptions, or institutions, which have to be distinguished from the real-world organizations, in this case the school boards. The new examination of 
this connection between institution and organization, taking also the example of the education system, is a contribution made by the other, previously-mentioned department at Stanford University, namely, the Sociology Department.

\section{Neo-Institutionalism}

Shortly before the School of Education at Stanford University initiated the research on numerous school reforms in the United States that led to the development of the grammar of schooling model, the Department of Sociology, upon the background of research findings on educational establishments, began to reformulate the traditional concept of institution, especially as coined by Max Weber, and to define it as distinct from the concept of organization. This distinction between institution and organization was made applying the model of loose coupling, which had been developed mainly within organizational psychology. This model describes the organizational connection between formal structures of an organization with the organization's activities, which are as a rule only very loosely coupled. ${ }^{23}$ Whatever model we make of the efficient, transparent organization of work, the actual processes in the organization mostly follow their own, very different logical courses that are not envisaged in the ideal-type models. Applied to the entire organization, this insight from organizational theory says that the formal structure of an organization does not so much affect the activities of the organization but is nevertheless not superfluous, because it does play a role, if not the role actually intended. The structure of the organization, namely, adapts to the expectations of society and culture and acquires in this way the legitimacy of the organization, thus safeguarding the vital question of resources. If today every organization - whether small companies or organizations of teacher education at schools of education worldwide - establish R\&D departments, that does not mean that the results of this research activity necessarily have any influence on the products, or on teacher education. Rather, the phenomenon of these certainly expensive establishments points to the generally widespread expectation that modern organizations have to have $\mathrm{R} \& \mathrm{D}$ departments and are otherwise not considered modern.

According to the thesis of loose coupling, the formal structure of an organization does not so much consist of influencing the activities of the organization but rather of presenting itself in public in a way that cultural expectations for the organization are satisfied and the organization appears publicly legitimate. For without public legitimacy no organization can survive in the long term. The concept of loose coupling thus points out that the formal structure of an organization is not tightly linked with the activities of the organization, as the activities follow their own logic of effectiveness and efficiency and do not have the primary aim of public legitimacy. ${ }^{24}$ Historical case examples show that loose coupling does not only not act as a disruptive factor; it is instead a constitutive element in organizations, and the attempt to link formal structure and activities tightly can lead to the disbanding of the organization. ${ }^{25}$

In other words: reforms that attempt to change the efficiency of the school through modern management structures or procedural changes - "change management" - do 
not change the performance of the school but rather the organizational structure of the school and thus secure in this way public recognition. The form of organization adapts to the institution, the cultural expectation. Measures of school performance then lead to the familiar disappointments that have confronted most school reformers since the school became seen as a tool for realizing a better future.

\section{The Real School at the Intersection of Vision, Pragmatism, and Feasibility}

Both the grammar of schooling and the thesis of neo-institutionalism explain why it is so difficult to reform the school and why the school never comes to resemble the picture painted by education reformers. This leads to two questions. First, whether the school is fundamentally rigid and cannot be changed. That is - seen historically - surely not the case. The school has certainly changed, massively even, if we compare the schools in 1800, 1900, 1950, and 2000. In those 200 years, the school became the public school that is open to all, and it became differentiated in a way that the transitions from one school level to the next are not determined by a student's family of origin but by the student's achievements and leanings. At least, that is the ideal, the culturally-embedded idea of a modern school, which is found also in the laws and regulations. For the school subjects there are usually grade-specific textbooks for the students and teachers - teachers who are well-educated, earn decent salaries, and have sufficient social security. The school, whatever disappointed reformers may claim, is a splendid success story of modern times.

This insight leads us to the second question, namely, what, then, made this success story possible, considering that the theoretical models point out so clearly the problem of governance of the school. I think that as yet research has paid too little attention to this question. For now, it offers only some indications that will need to be investigated more broadly:

- First, the eighteenth century vision that the upbringing and education of the young makes possible a modern age of justice and prosperity was successfully translated into an organizational form, the school, or educational establishment. Through this, the school received high legitimacy and considerable resources for its development.

- Second, the loose coupling phenomenon protected the school against reform demands that contradict the grammar of schooling.

- Third, two sorts of collective expectations concerning the school should be distinguished, namely, the expectations of reformers - who at this current time want to define the school according to global patterns - and the collective expectations of the local and regional democratic public.

- Fourth, it is to be expected that local and regional expectations of the school, while also oriented to the future, are far more pragmatic than the visionary rhetoric of the reformers. 
- Fifth, for its form or grammar, the school has to thank an historical interaction process that oscillates between the utopian visions of the future of reformers, pragmatic expectations of the local public, and actual feasibility.

Upon this background it becomes clear that the school cannot be governed simply by ideas, and this is not because teachers are stubborn or because the idea of school subjects or lesson periods is fundamentally wrong. School subjects and periods as identical units of time have proved useful in practice, and the fact that they can be criticized but that they have continued to survive and even became more differentiated through the course of the past 200 years shows them evidently to be convincing concepts of the public school. Moreover, teachers are not obstinate; on the contrary, they usually try hard to mediate between actual feasibility, local expectations, and utopian visions. However, this can all too frequently - mainly if exaggerated expectations gain the upper hand in the contemporary discourse - shape the mental dispositions of young teachers in a way that they come to view their school practice as failure.

The school developed within this interaction model of vision, local pragmatism, and actual feasibility, cannot be reduced to one of these pillars. Here, there are still great gaps in the research, for it no doubt dealt with the visions and reforms and reacted to failure with new visionary strategies, and now research is working on empirical investigation of processes in the classroom. But empirical research has never investigated what it is that in a way stands at the center between great vision and classroom, what it is that the public actually expects of the school, the public that, after all, pays for the education system. That is, we know what the World Bank, what UNESCO, or the OECD expect of the education system, and we know quite well, based on the TIMMS Study, what mathematics instruction looks like in classrooms around the globe, but we know astonishingly little about what those responsible in a democracy - the public — want of the school. And we do not know at all what factors in this intersection of vision, pragmatic expectation, and actual feasibility were decisive for the success story of the school in the last 200 years. Abolishing the democratic form of this organized public, the school board, is particularly senseless upon this background, because it does not do away with it but only robs it of its organizational expression. The collective expectations of the local public would lose their organized form of expression, but the expectations would by no means disappear.

The yet-to-be examined historical, sociological, and political reconstruction of this success story will have to not only reduce the promise of modern school development to what is feasible but also qualify visions that hold the school responsible for a more just future. This understanding will not in the least protect teachers, who often embark upon their careers with great enthusiasm, not reckoning with the friction between noble visions, public expectations, and real feasibility. To characterize teachers later as inactive or as stubbornly refusing to listen is, in the context of this need for research, almost cynical and in the least unjust. 


\section{Notes}

1. Guest lecture at Queen's University, Kingston, Canada, November 29, 2007. An earlier version of this paper has been presented at the University of Luxembourg, June 12, 2007. I wish to thank the reviewers for their helpful comments and Sandra McCance for her generous help in editing the text.

2. Jean-Jacques Rousseau, "Émile ou de l'éducation." In CEeuvres complètes de Rousseau, vol. IV, eds. B. Gagnebin and M. Raymond (Paris: Gallimard, 1969), 239-868.

3. Ibid., 879-924.

4. International Bank for Reconstruction and Development/The World Bank, World Development Report 2007: Development and the next generation. Washington D.C. (2006).

5. National Commission on Excellence in Education, A Nation at Risk. The Imperative for Educational Reform. Washington D.C. (1983).

6. For a more detailed analysis see Daniel Tröhler, "The New Languages and Old Institutions: Problems of Implementing New School Governance." In Educational Research: Why 'what works' doesn't work, eds. P. Smeyers, and M. Depaepe, (Dordrecht: Springer, 2006), 65-80.

7. See, for example, the 1983 report Action for Excellence, issued by the Task Force on Education for Economic Growth (Washington, DC, 1983) or the 1986 report, A Nation Prepared: Teachers for the 21st Century, issued by the Task Force on Teaching established by the Carnegie Forum on Education and the Economy (Washington, 1986): "There is a new consensus on the urgency of making our schools once again the engines of progress, productivity and prosperity" (Task Force on Teaching, 1986, p. 2); W. Firestone, S. Fuhrman, and M. Kirst, "An Overview of Education Reform Since 1983." In The Education Reform Movement of the 1980's. Perspectives and Cases, J. Murphy ed. (Berkeley: McCutchan, 1990), 349-64.

8. National Commission on Excellence in Education, $A$ Nation at Risk.

9. Ibid., 5.

10. Ibid., 7.

11. "I know no safe depository of the ultimate powers of the society but the people themselves; and if we think them not enlightened enough to exercise their control with a wholesome discretion, the remedy is not to take it from them, but to inform their discretion" (Jefferson, 1820, quoted in National Commission, 1893, p. 7). This sentence is from a letter Jefferson wrote to William C. Jarvis in response to a collection of essays published in that same year. Jefferson, Thomas, Letter to Charles Jarvis September 28, 1820. In Jefferson's Political Writings, eds. J. Appleby, and T. Ball, (Cambridge: Cambridge University Press, 1999), 381-2.

12. Firestone, et al., "An Overview of Education Reform Since 1983", 349-64.

13. C.E. Finn, "Reinventing Local Control”, Education Week 11, no. 23 (January 1981): 32.

14. D. T. Conley, Who Governs our Schools? Changing Roles and Responsibilities (New York: Teachers College Press, 2003), 11.

15. Ibid., 15, 144.

16. Ibid., 146 .

17. Ibid., 179 . 
18. L. Cuban, "Determinants of Curriculum Change and Stability, 1870-1970. In Value Conflicts and Curriculum Issues, eds. J. Schafferzick and G. Sykes (Berkeley: McCutchan, 1979), 139-96; L. Cuban, How Teachers Taught. Constancy and Change in American Classrooms 1880-1990 (New York: Longman, 1984); L. Cuban, How Teachers Taught. Constancy and Change in American Classrooms 1880-1990. $2^{\text {nd }}$ ed. (New York: Teachers College Press, 1993). 237.

19. Cuban, How Teachers Taught. Constancy and Change in American Classrooms (1984),

20. D. Tyack and W. Tobin, "The Grammar of Schooling: Why Has It Been So Hard to Change?”, American Educational Research Journal 31, no. 3 (1994): 453-79.

21. D. Tyack and L. Cuban, Tinkering toward Utopia. A century of Public School Reform (Cambridge, MA: Harvard University Press, 1995).

22. Ibid., 60-84.

23. R.B. Glassmann, "Persistence and Loose Coupling in Living Systems", Behavioral Science 18 (1973): 83-98; K.E. Weick, "Educational Organizations as Loosely Coupled Systems", Administrative Science Quarterly 21, no. 1 (1976): 1-19.

24. J.W. Meyer and B. Rowan, "Institutionalized Organizations: Formal Structure as Myth and Ceremony", American Journal of Sociology 83 (1977): 341, 357, 361; see also J. W. Meyer, and B. Rowan, "The Structure of Educational Organizations." In Environments and Organizations, eds. M.W. Meyer et al. (San Francisco: Jossey-Bass, 1978), 79.

25. A. Bosche, Schulsteuerung im 18. Jahrhundert: Eine historische Analyse der institutionellen Einbettung von Schulorganisationen. (Saarbrücken: VDM Verlag Dr. Müller, 2008); Daniel Tröhler, "Curriculum, Languages, and Mentalities." In Towards a New Curriculum History, ed. B. Baker (Rotterdam: Sense, in print). 